\title{
Gerontocracy of the Buddhist monastic administration in Thailand
}

\author{
Jesada Buaban ${ }^{1^{*}}$ \\ ${ }^{1}$ Indonesian Consortium for Religious Studies, Universitas Gadjah Mada, Indonesia \\ * Corresponding author \\ E-mail address: jesada.tee@gmail.com \\ DOI: https://doi.org/10.21107/sml.v4i1.9880
}

\begin{tabular}{|c|c|}
\hline Article Info & Abstract \\
\hline $\begin{array}{l}\text { Keywords: } \\
\text { dhamma studies } \\
\text { gerontocracy } \\
\text { Sangha Council } \\
\text { secularism } \\
\text { Thai Buddhism }\end{array}$ & $\begin{array}{l}\text { This paper examines the monastic administration in Thai Buddhism, } \\
\text { which is ruled by the senior monks and supported by the government. It } \\
\text { aims to answer two questions; (1) why the Sangha's administration has } \\
\text { been designed to serve the bureaucratic system that monks abandon social } \\
\text { and political justices, and (2) how the monastic education curriculum are } \\
\text { designed to support such a conservative system. Ethnographic methodology } \\
\text { was conducted and collected data were analyzed through the concept } \\
\text { of gerontocracy. It found that (1) Thai Buddhism gains supports from } \\
\text { the government much more than other religions. Parallel with the state's } \\
\text { bureaucratic system, the hierarchical conservative council contains the elderly } \\
\text { monks. Those committee members choose to respond to the government } \\
\text { policy in order to maintain supports rather than to raise social issues; (2) } \\
\text { gerontocracy is also facilitated by the idea of Theravada itself. In both theory } \\
\text { and practice, the charismatic leader should be the old one, implying the } \\
\text { condition of being less sexual feeling, hatred, and ignorance. Based on this } \\
\text { criterion, the moral leader is more desirable than the intelligent. The concept } \\
\text { of "merits from previous lives" is reinterpreted and reproduced to pave the } \\
\text { way for the non-democratic system. }\end{array}$ \\
\hline
\end{tabular}

Citation suggestion:

Buaban, J. (2021). Gerontocracy of the Buddhist monastic administration in Thailand. Simulacra, 4(1), 43-56. https://doi.org/10.21107/sml.v4i1.9880

Received 8 February 2021; Received in revised form 3 April 2021; Accepted 9 April 2021; Published online 25 June 2021. 


\section{Introduction}

Buddhism is the mainstream religion in Thailand, which is followed by more than $90 \%$ of the total population, and around 300,000 men decided to live the monastic lives as monks and novices (Rabassó \& Rabassó, 2018). However, a total number of monks and novices in both Mahanikaya and Dhammayutta Orders is dynamic because the rituals of ordination and disrobe are arranged every day. That is because ordination is Thailand is considered as a duty that all men should practice even for a short term. Buddhism used to play a vital role in nation-building, creating identity, and legitimizing the Thai elites especially during the regime of absolute monarchy (McCargo, 2004). However, though Thailand has been changed to a democratic country in 1932, the monastic administration still maintains the hierarchical organization and centralizes its power. Monks who become the leaders of temples, sub-districts, districts, provinces, regions, and the committee of the Sangha Council (Mahatherasamakhom: in Thai) are totally from appointments, not from elections (Tuan, 2018). As a result, it is not surprising to find that most of those leaders are very old because they are more famous and respected than the younger monks. In technical term, ruled by the old man was called gerontocracy. This paper questions (1) why the Sangha administration has been designed to serve the bureaucratic system ultimately monks abandon social and political justices, and (2) how the monastic education curriculum are designed to support such a conservative system.

Many scholarly works focus on Theravada Buddhism and Thai society. According to Kulabkaew (2012), Swearer (2010), and Jory (2002), Buddhism in Thailand has been reinterpreted to support social status and elites' legitimacy. Meanwhile some scholars asserted that the Sangha institution was instrumentalized to assimilate different groups of people into Thai state's power, namely, Nicholas (1999), Tiyavanich (1997), and Taylor (1993). However, reinterpretations of Buddhism also serve ordinary people in daily activities as discussed by Reynolds (2016, 2015), McDaniel (2011), Kitiarsa (2007), Tambiah (1984) and Kirsch (1977). Moreover, some studies explore the ways that religions adapted to local contexts (including cultural, social, and political environments), due to the stream of modernity and intellectual critiques. Winichakul (2015), Scott (2009), and Eaiwsriwong (2003) proposed that Buddhist value in Thailand had been changing from the charismatic leaders who are experts in meditation to those whose reputation is to support people's business purposes. This changing value is motivated by capitalism as well.

In general, various works seem to perceive Thai Buddhism as a tool for political objectives, on the contrary, it should also be mentioned that Buddhist institutions instrumentalize political power to serve their aims as well. The empirical examples from Sri Lanka, Myanmar, and Thailand were studied by Helbardt et al, (2013). The researcher, in this paper, proposes that Thai monastic institutions, which are ruled by the old monks, always require supports from the government and do not want to be free from the state's control. Secularism and humanist issues are therefore not raised because of several reasons. In consequence, relationships among the old administrative monks, the hierarchical style of organization, and the semi-democratic government of Thailand should be systematically studied.

\section{Method}

Ethnographic methodology was adopted in this research paper. The author had been joining the monastic life as a monk for almost two decades (2000-2018) in Southern 
and Central Thailand. Therefore, some data were written as a self-reflection. However, in order to write this project, the author conducted fieldwork again in Nakhon Sri Thammarat, Suratthani, and Bangkok, for five months in 2018. Participant-observations were conducted by staying with monks and novices in various temples, while indept interviews with five monks who worked under the Sangha Administration, and five monks, as well as ex-monks, who tended to criticize that particular system. However, in order to protect informants, pseudonyms were used here. Then, collected data were analyzed through the concept of gerontocracy, which has been paid attention by various scholars in social sciences. In terms of Buddhist texts, this research employed both primary sources namely the Pali Tipitaka and secondary sources such as religious textbooks and explanations by Thai monks in order to provide some differences and discuss how the Thai curriculum have been interpreted to preserve gerontocracy and promote absolute monarchy.

This paper is organized into three parts; (1) Ruled by the Old Monks: elucidates the governance of old representatives who really have no power and creative ideas to run their organization. In this section, it finds that the main role of Sangha administration, which is supported and approved by the government, is to respond to the state policy. The case of Dhammakaya is exemplified to show the dictatorial aspects of the Thai Sangha Council and the state's authorities, which always reject the diversity of religions and cultures. Besides, while those old monks are weak in working, the real workers are their secretary monks. However, it does not mean that those secretaries can freely run organizations, because they are chosen to work for the old system. (2) Theravada Way of Governance: explains the perspective of governance in Theravada tradition. Both theoretical ideas depicted from the scriptures and practical ways of life of Thai Buddhists are analyzed to reveal why Thai Buddhism is fit to gerontocracy. (3) Thai Buddhism for Secular State and Welfare State: demonstrates relationships between religion and the Thai state. Islamophobia is also stated here as one of the main causes that encourages monks struggle for the state's support and deny secularism. While some groups of young monks protested to demand secularism, they were accused and punished by the Sangha Act of insulting the old monks and systems. Welfare State and Thai Buddhism are additionally discussed to analyze why Thai Buddhism does not respond to social issues.

\section{Results and Discussion}

\section{Ruled by the old monks}

Literally, monks are people who renounce the worldly life and follow the monastic codes (Bhikkhu: in Pali language). However, monks in many traditions especially Thai Theravada, according to Bunnag (2007), are not separated from their family members, because the aim of ordination is not only to practice meditation and gain Nirvana as mentioned in the scripture, but in practice, the monkhood can help candidates to elevate their social status. Many poor families tend to send their children to join the monastic life for education purpose and many of them choose to disrobe after graduated. This kind of ordination becomes one of the Thai cultures, which is still widely practiced nowadays. When the monkhood in the Holy Scripture is different from the practical norm, it is not odd to find that livelihood of those men after ordination cannot be free from worldly issues. Many of them are interested in learning religion and teaching laypeople, while many of them try to join the monastic administration, in which monks work as state's bureaucrats and earn salaries from 
the national budget. Notably, becoming a monk gains a lot of advantages such as, free from conscription for army service if he maintains a monastic life until the age of 30, accessing to education, if passing the Pali exam Grade IV, will be able to work in the military as a high-ranking soldier. Moreover, if maintaining in the monkhood, many priorities from society such as special seats in the public transportation, airplane, and so on are available for them (Kamjaiboon, 2019).

The old monks are generally approved in the positions of abbots until the Supreme Patriarch (Sangharaja). All positions get salaries from the government and interestingly there is no retirement age for these two positions. It means that those positions will remain until the death time. For the leaders of sub-districts to the leaders of regions, the retirement age is at 80 while other worldly Thai bureaucrats are at 60 (Thirapanyo \& Pipitkun, 2018). Consequently, most of ranking monks are not active due to their physical conditions. It then comes to the question that who do really govern? The answer is that their secretaries, young monks who are chosen due to their loyalty to the old monks and old system. However, though this paper employs the concept of gerontocracy, it does not generalize that all elders are passive or conservative as found in many kinds of stereotype (Wilkinson \& Ferraro, 2002). Instead, it persuades to analyze the Buddhist organization run by the old monk, which is also supported by religious interpretations.

Based on the concept of gerontocracy, it emphasizes in age criteria, perhaps the +60 -year-old leader is desirable (Atella \& Carbonari, 2017; Bytheway, 1995). However, this system always gives an opportunity to the young generation, in the case that it must make sure that the next candidates will be loyal to the old system. In this aspect, it can be said that giving some positions and power to the next generation is possible in order to prevent them from protesting the system. As a result, though some young monks are approved to work, but they must respect the old law. This causes many modern educated monks decided to leave the monkhood instead of serving the old system, according to the interview with Sakda (pseudonym), an ex-monk who works as a high school teacher now, in 2019. This is also one of the reasons that there is no protest and reform from the young monks themselves. According to the interview with Samath (pseudonym), secretary of the regional leader in March 2018, any monk who wants to elevate the high ranking should create relationships with the secretaries, because they are the ones who gather the names and propose to the regional leaders. Theoretically, semidemocratic or dictatorial regimes experience more violence than "pure" democracies because the later regimes allow opposition groups to access power in a coming period (Berton \& Panel, 2018), however, it cannot be denied that the dictatorial regime also has a trick of governmentality such as employing religious teaching to affirm its legitimacy, as will be discussed below.

In general, the annual work of Sangha Administration is limited into few things namely, elevating the ranking positions of some candidate monks, collecting the list of those who want to take exams in Pali language and Buddhist Studies (Naktham), and arranging the blessing ceremonies to the king and other monarchical members. There is, of course, no room for raising issues about democracy and social welfare. In order to see more effects from such administration, the case ofDhammakaya should be demonstrated to show that Buddhism in Thailand is very fragmented. Each organization is actually free to run their social activities as long as it still identifies itself as under the Thai Sangha council. This causes a lot of problems, like the Dhammakaya, whose teaching is 
different from the mainstream Theravada, but it cannot be allowed to generate the new sect. The law was always reinforced to deal with this problem instead of freeing them to grow in their ways (Kulabkaew, 2019).

Dhammakaya is one of Buddhist temples under the Thai Sangha Council. It faced a lot of problems with the government and other Buddhist monks. Its way of reinterpreting of Theravada Buddhism is criticized by many scholars; one of them is P.A. Payutto, a conservative scholar. In addition, Dhammakaya foundation and the abbot were accused to commit corruptions, which ultimately brought to arrestment the abbot and secretaries in 2017. That situation satisfied many Buddhists who perceive Dhammakaya as heretic. Unfortunately, neither Thai people nor Dhammakaya followers themselves solved the problem by separating religion from the state based on the concept of secularism. In turn, while the first group wants to use the state's power to destroy Dhammakaya, Dhammakaya itself also tries to strengthen relationships with the government in order to gain more supports and make sure its stability. This is one of several reasons why Thailand cannot develop to the secular state. As usual, the Sangha administration, which is ruled by the old monks, was passive in solving this problem.

The passiveness of the Sangha administration can be understood as a dilemma. It means that if Dhammakaya is allowed to stand outside the Sangha administration, other Buddhist organizations must also want to go out from that conservative institute. In turn, if the Sangha administration is active in solving conflicts and punishing Dhammakaya in terms of its heretic doctrine, Sangha administration itself must be condemned by scholars, secular people, as well as NGOs who support pluralism. In this respect, the Sangha administration can be seen as the dead-standing tree that cannot function anymore in the modern time. Its best way in maintaining the power is to try to be neutral and playing no role in any risk situation. In so doing, its way of running organization is sometimes called the "Rule of Anicca" as discussed below.

\section{Theravada way of governance}

Theravada is one of the main three schools in Buddhism apart from Mahayana and Vajrayana. It literally means those who believe and follow what is taught by the "old monks." Of course, the term "old monks" here refers to 500 Arahantas who participate for gathering the Buddha's teaching after three months of the Buddha's passing away. Pali is the language used to note the Theravada scriptures, which have been memorized and written from generation to generation. Until now, most Theravadins always perceive their school as authentic (Gornall, 2020). As depicted in the Mahapari nibbana sutta No. 141, the Buddha allowed monks to edit and adapt some monastic codes if they see something not suitable with particular time and place. However, those 500 arahantas agreed to follow whatever said by the Buddha without changing or adapting anything. This makes the Theravada's identity different from Mahayana and Vajrayana, while those two schools are able to adapt teachings and monastic codes to respond to the modern world. However, it does not necessarily mean that Theravada does not change at all. Thai monks gain salaries and work as state's bureaucrats are the new things not based on the Pali scripture. This kind of adaptation occurs as a social acceptability, but they do not change the monastic codes in the scripture.

In practice, Thai people tend to respect the old monks. Teachings from the forest traditional masters, Luangpu Mun, Luangpu Dul, Luangta Maha Bua, and so forth are 
quoted much more than the Pali scriptures. King Rama IX often visited temples of the old famous meditative monks. Similarly, Khruba, famous traditional monks in Northern Thailand, are always the old monks. Though some young monks begin to establish themselves as the reincarnation of previous Khruba, they still must pretend to behave like the old monks, using sticks, chewing betel, and so on (Duongkaew, 2016). The characteristic of charismatic leaders in Theravada is not only from reincarnation as found in Hinduism, but they also have to practice meditation for a long period, full of self-control, destroy the negative emotions; greed, hatred, and illusion as much as possible as found in Foucauldian idea (Voyce, 2016). It means that religious practices can be seen as bio-power used to train and control its members. In addition, it cannot be denied that those who pass such tests will be appreciated and gain legitimacy. Of course, such kind of character is suitable for the old man rather than the younger. It is therefore normal to find that most of the respected monks are old and interestingly they are also approved to play a vital role in administrative positions in terms of the head of the monastery and many other levels.

After the three-month retreat of Theravada Buddhists in the rainy season, there is an important ritual called Pavarana. The purpose of Pavarana is to open an opportunity for monks who stay in the same temple to warn or criticize each other in order to develop one's behavior. This ritual in Theravada countries, especially Thailand, cannot be functioned because Thai people also have a norm of respecting the senior. It means that to criticize or even to question the older is considered as impolite. Not only among the members of monastic orders, but arguing teachers of students in the secular schools is also viewed as a negative manner. Consequently, the structure of Sangha organization is different from the modern democratic system that many parts of members can equalize the power and examine each other. On the contrary, it maintains the top-down style, and reinterpret Theravada concepts to serve its system. The next two sections are elaborate examples.

The researcher is going to entitle this part as 'rule of Anicca' or 'administration of uncertainty' todemonstratethegerontological way of Sangha administration in detail. When the old monks must be respected, it also means that their administration should not be questioned. Anyone will be elevated in the higher-ranking status is up to this dictatorial council. Some scholars such as Visalo (2003) and Sangkhawijit (2017) view the requirements to upgrade monk's ranking as problematic, because it depends on achievements of constructing expensive pavilions or chanting halls. This limits the ranking position to those monks who are respected and gain a lot of donations only. On the contrary, Pirapat (pseudonym), a Ph.D candidate in Asian Studies Program, argues that this is really not a problem, because to find donation in Thailand is not difficult, and most of the abbots have pupils to support their projects. The main obstacle is that, though many monks already fulfill the requirements, only those who are familiar with the old leaders in the council will be elevated their ranking. This kind of administration, according to Prajak, an abbot of village $\mathrm{A}$, is called the "Rule of Anicca" or Administration of Uncertainty. It means that no one can predict the future that he will be rewarded or not though he works very hard. That is because everything depends on the old boss.

"How many times do I have to give sermons in order to be elevated in ranking?" Prajak asked Samai, one of the high-ranking members in the Sangha Council. The answer is that "giving sermons is a duty, don't expect anything in return, if you perform a good action, based on the idea of Karma, a 
good result will come to you automatically. Moreover, giving sermons should be conducted by the positiveintention, educating people in the Buddha's teaching, not by the negative courage, gaining the high ranking." This answer is based on the Buddhist teaching of action and result. However, it is also based on the law of uncertainty, because people cannot know when and what kind of result will happen. This kind of explanation serves the dictatorial administration well. Ven. Prajak argued that "the administration must base on certainty, which is clear and fair for everyone. If the contract mentions that he will be elevated after giving sermons for 100 times, therefore, if anyone can reach that point, he must be rewarded. But now, only those who are familiar with and serve the old administrative monks can get the ranking reward."

From the above examples, it does not mean that the researcher agrees with such centralized Sangha Council, which is tied to the state power. The researcher totally supports secularism. However, if Thai monks and government want to maintain such relationships, the fair and clear methods as proposed by Prajak should be considered. Organizations should base on consensus. Therefore, in order to prevent corruptions, the workers must be investigated by the fair system, not to find the old ones who claim his morality and works without transparency. The next section will demonstrate how the Sangha's education paves the way for preserving the old system.

Though one of the purposes of modern education aims to deal with traditional or supernatural belief, which is considered as unscientific according to the modern knowledge driven, the researcher argues that it still cannot change the worldview of Buddhists in general. This section discusses the monastic education system that has been organized by the national Sangha administration namely Dhamma and Pali
Studies for a century. These programs were designed to systematize religious knowledge by providing the national curriculum based on the Pali commentary texts as well as Thai Dhamma books, but they ultimately function for strengthening the charismatic leader position and unquestionable beliefs, instead.

Dhamma Studies (Naktham) has been initiated in 1892 in Wat Bowornives Vihara, the main Dhammayutta monastery that has been supported by the monarchy. That particular period was under the regime of king Rama VI, in which national education had also been flourishing. However, it is assumed that the Dhamma Studies had been started before that by Vajiranyana Bhikkhu (who was becoming a monk since 18241851 and later became the king Rama IV). When Buddhist monks played an important role in teaching the villagers, educating those monks in the state-based knowledge was therefore important. In 1912, the state-based curriculum divided Naktham program into two kinds; Ordinary (Saman) and Extraordinary (Visaman). Three main subjects have been taught in the Ordinary Program; Buddha's biography, Buddhist doctrines, and Monastic Codes, while the Extraordinary Program also had the basic Pali skills (Pansa, 2018).

Interestingly, the new Act of national military was announced in 1905. All Buddhist monks and novices must participate in the national military conscription as other Thai male did. The Sangha council therefore negotiatedbyproposing thatonlyuneducated monks and novices must disrobe and follow the military program. It means that anyone who passed the Naktham exam would have rights to continue his monastic life. This new Act, undeniably, helps to promote the Naktham program for those who do not want to join the military training by becoming a monk and focusing on Buddhist studies (Chandaeng, 2019). Notably, Naktham program is centralized by the National 
Dhamma Study Unit, an organization under Dhammayutta's control (Sairarod \& Kumar, 2020). It means that monks and novices have to study Theravada Buddhism in the way of national interpretation, while other ways of interpretations are not taught. Simply put, this kind of state's curriculum does not support multiculturalism in the modern world, because its key purposes are to prioritize Thai Theravada Buddhism and preserve the old system.

The concept of sovereignty (adhipateyya) in Naktham curriculum exemplifies my claim. According to the page 22 of Dhamma Book II provided by the Office of National Buddhism, the term adhipateyya is translated as sovereignty, power, or rule. Interestingly, in chapter 3 of Naktham Grade II, it translates this term as "rule" in order to promote the national political idea. There are three kinds of political rules in this book, as mentioned by this curriculum, namely; (1) Rule by Dictator (atta-dhipateyya), Rule by the Majority (loka-dhipateyya), and (3) Rule by the Dhamma (dhamma-dhipateyya). The second one, majority, refers to democracy, and also provides the negative explanation by emphasizing that the majority of the fool and immoral will make to country backward. Therefore, the best thing is rule by the Dhamma, meaning that the ruler practices Buddhism and organizes without bias (Office of National Buddhism, 2016). Strictly speaking, this kind of political power does not care about the process of voting the leader, instead, it prefers the moral one, the king and military leader for examples, which can be called the moral dictator in Buddhadasa's idea (Puntarigvivat, 2003). This way of teaching may help to produce the anti-democracy monks on the ground that democracy, based on Buddhist tenets taught in Thai monasteries, is opposite to the Dhamma or righteousness.

In contrast, these three sovereignties in the Pali text originally refer to the powers that motivate people to do good things. Atta-dhipateyya is used to demonstrate a person who does it by his own desire (selfmotivation). Lokka-dhipateyya is used to explain a person who does it by being persuaded by other people. And Dhammadhipateyya is used to denote a person who does it by believing that such a thing is righteous. Nonetheless, all three factors are good under the reason that they motivate people to do good things, but is has been reinterpreted in the new way to destroy the political idea of democracy in Thailand, where the absolute monarchy is still needed, especially by the old monks in the Sangha council.

Similarly, the Pali Studies is another curriculum designed to centralize interpretations of Buddhist knowledge in Thailand. It has been started since 1928, while the textbooks are from commentary sources. The curriculum is quite the same for a century and recently it is controlled by Mahanikaya monks, Wat Paknam and Wat Samphraya in Bangkok. A novice who graduates the Pali Grade IX (the highest level) before the age of twenty-three will be ordained in the palace, and supported by the king. 126 USD from the state's budget will be provided for all clerical students who pass the ninth level of Pali exam as a salary.

In addition, this higher level can be approved as a university degree in Master of Arts. There are always some efforts to elevate it to the Ph.D. but was rejected by the Ministry of Education. In general, Thai people have to study about 12 years to accomplish their master degree; 6 years for secondary / high school, 4 years for B.A. and 2 years for M.A., while the monk can graduate Pali Grade IX within 8 years, is approved to be equal with M.A. Of course, this phenomenon happens because of the Buddhist state of Thailand, while other religious language skills such as Arabic and Hebrew have not been approved by the government. 
It is generally believed that Pali language is more difficult and complicated than other languages, therefore a few students will pass the exam each year. Based upon this claim, it is therefore reasonable to say that merits (punna) are the main factor to success. The author, an ex-Pali student, was always recommended to pray, meditate, as well as conduct pilgrimages, on the ground that those acts would facilitate in passing an exam. More interestingly, if the wise student failed the exam and wanted his answer sheet to be rechecked, he will be told that the committee members are fair and full of awareness, because they are senior monks who should be respected. So, all faults are his' and he should accumulate more merits for the next round. The concept of meritmaking appeared in Pali curriculums will be elucidated below. Simply put, it can be said that the seniority of those old monks is also used to claim their respected and unquestionable status.

A sentence, the successful person must accumulate merits from the previous lives or pubbekatapunnata, has been often mentioned in Pali curriculum Grade IV (Sirimaggalacariya, 1987). Though the word "pubbe" can be interpreted as the "past" of this very life, most examples shown in this book refer to the previous lives, the processes to enlightenment of the Buddha for example. In consequence, our effort in the present is not only the key factor to determine our success. In fact, the unfair or unquestionable system makes Buddhists to believe in merits of the previous lives, because it is only one way to explain their destination in a society ruled by the law of impermanence (Anicca). The next section continues to trace the development of Theravada Buddhism in social aspects and analyze why its doctrines are difficult to be interpreted to serve modern society.

\section{Buddhism for secular state and welfare state}

Thailand recognizes five religions namely; Buddhism, Islam, Christianity, Hinduism, and Sikhism, as under the state support. Buddhism receives a budget much more than other recognized religions. Sangha administration is supported by the monarchy and government, it is therefore difficult to discuss secularism as long as the monarchy is so strong and monks are considered as the king's partner. Monks always arrange various ceremonies to support the king's legitimacy (Larsson, 2020), therefore, to secularize the monks is like to destroy the monarchy because the king's legitimacy is also eliminated.

Many Thai monks do not support secularism because of several reasons. Firstly, Buddhism is already the mainstream religion in Thailand that get a budget from the government the most. Secondly, all welfares as mentioned above such as priority seats in the public sphere and transportation will disappear if religions are removed from the state's support. Thirdly, and most importantly, Islamophobia is spreading in the Buddhist communities. Some Thai Buddhists believe that their culture will be swallowed by Islam and Buddhism in Thailand would be destroyed as happened in Indonesia in the 13rd century (Buaban, 2020). Of course, this kind of fear clearly reveals the weakness among Buddhists themselves in the sense that they cannot organize religious institutions and spread teaching to attract the new followers without any help from the government. The case of anti-hijab will exemplify this claim.

Wearing Hijab of Muslim students was protested by Buddhist monks and laypeople in many places of Thailand, especially in the case that those schools are in the temple area. Muslims try to fight by claiming religious freedom, which is guaranteed by 
the Thai constitution. However, the Ministry of Education supported Buddhists' demand by using the Sangha Act of 1962. This Act clarifies that, schools in the Buddhist temples are considered as the Buddhists' property. Therefore, the authority must belong to the abbots and their instructions should be respected. It means that if the abbot does not allow Muslim students to wear hijab, his command must be final. Rakchart Chusuwan, the leader of Buddhists for Peace in Three Southern Provinces, as reported by BBC Thai (2018), stated that it was important to protest wearing Hijab in the Buddhist schools in order to maintain peace and prevent separatism. Muslim students should not differentiate themselves from Buddhists. If we allowed them to wear Hijab, they will ask for the halal kitchen in the next step. According to Rakchart and other Thai officials, religious peace can be gained through unity, not diversity.

However, not only Buddhists ask many supports from the government, Muslims themselves also conduct such behavior. Supporting Muslim pilgrimage to Saudi, initiating halal industry, providing salaries for Muslim leaders, and so on are also supported by the government. Conflicts between Buddhists and Muslims can be seen when one religion got support while another did not. Unfortunately, both of them never want to find the solution by discussing secularism. Therefore, concepts of human rights and democracy will be referred to only when they lose some advantages but not for the sake of other religions.

Welfare state is the system that allows all citizens to equally access the state's services such as education, medication, and so forth. This system can occur if all citizens, especially the rich, pay more tax. In Theravada idea, it also difficult to initiate the welfare state because the gap between rich and poor people is something to be preserved in order to exemplify the concept of Kamma or actions in previous lives.

Social status of all beings, according to the Pali scriptures, is different because of their actions in the previous lives, Kamma. High-class people are from those who used to conduct a lot of generosity, help other people and animals. While the poor are opposite (Silasutta, 213). Therefore, this particular life is the result of their previous actions that must be faced, of course, they are supposed to develop their behavior in order to get the new good life, but they must accept that fact as fundamental teaching. According to Jory (2002), the Siamese elites could gain religious and political legitimacy through this idea, in which the poor people perceived the rich and the leaders as from moral actions at least in the previous lives.

In order to educate Buddhists in the Kamma belief, the gap of social status must be maintained and reproduced. If everyone can access the good quality of medication, the results of previous actions will be destroyed. If A, for example, dies because of inaccessibility of good medication, it means that he deserved such a result because of his bad actions in a previous life. What the Theravadins must do is to conduct charity in order to get a better life and to meditate for gaining the purity of mind, Nibbana. Because of this idea, Theravada is normally perceived as individualism, which is totally different from Mahayana, a school of thought that tends to be more focused on social structures. Mahayana organizations such as Tzu Chi and Soka Gakkai are therefore famous in building hospitals, schools, houses for the poor, providing scholarships for students and so on (Julia, 2005; Metraux, 1996).

In addition, when a group of young monks and novices, called the Carrot Gang, protested the government as well as the Sangha council in 2020-2011, alongside prodemocracy groups, they were accused of 
insulting the Supreme patriarch (Sangharaja) that should be punished for a year in prison, according to the Sangha act, article 44 , and of course it was cooperated by the state's police. In fact, those monks and novices criticized the non-updated status of Sangha system and reciprocal relationships between state and religion, but to respect the old powerful monks were still used as a reason to reinforce the law to prevent criticism of dictators and gerontocracy.

Relationships between Thai monks and the king should also be addressed. The Sangha Council, issued by dictatorial government in 1962 and used until today, is not corresponding to democratic system. Monk leaders are not from elections, but approved based on their rankings. In general, the king approved the supreme patriarch, while other rankings were approved by the Sangha Council. Nonetheless, in 2020, the king wanted to broaden his power by becoming the one who approves all kinds of high-rankings (Chaokun in Thai status), therefore the Sangha Council deals with only the low-rankings (Phrakhru). In fact, some Sangha Council members are not satisfied with such a change, according to an interview with Ven.Suthat, a provincial secretary monk, but they preferred to keep silent on the ground that the power of the king is overwhelming. As a result, it can be said that gerontocracy in Thai Buddhism is also preserved by the monarchy. It is a reciprocal relationship in the sense that those old monks are approved to play a ruling role, while they also help to educate people to be loyal to the king as an significant icon of the Thai identity. Of course, both of them have not only a traditional norm to prevent criticism, but also a criminal law; article 112 for Lèse-majesté and article 44 of the Sangha Act for insulting the Supreme Patriarch. It cannot be denied that gerontocracy is an obstacle for democratization (Rotila \& Celmare, 2017), while the monarchy and
Buddhist institution have not been reformed to respond to democratic system.

\section{Conclusion}

Gerontocracy or "rule of old men" in the Thai monastic administration is supported by Theravada concept of respecting the old priests who exert to reduce negative emotions as suggested by the Buddhist scriptures. Their legitimacy automatically came after entering the monastic life for many years. Perhaps, this is normal in a semi-democratic country like Thailand, where many people still prefer moral dictators rather than those who are from elections. Also, it found that the young generations who are loyal to the old system and old monks are always chosen to work in this organization in order to prevent their protest. However, this paper proposes that monastic gerontocracy causes religious organizations passive in raising democratic and social issues. Those powerful monks commonly seek stability by strengthening relationships with the government and the monarchy rather than supporting human rights. The case of Dhammakaya and AntiHijab are depicted to show the problems in terms of idea and management of the old monks as well as other Buddhists in promoting peace in the diverse society. Moreover, the national curriculum for monks are also designed to preserve such a conservative system, in which the old monks should be respected and are unquestionable.

\section{Declaration of Ownership}

This article is my original work.

\section{Conflict of Interest}

There is no conflict of interest to declare in this article. 


\section{Ethical Clearance}

This study was approved by the institution.

\section{References}

Atella, V., \& Carbonari, L. (2017). Is gerontocracy harmful for growth? A comparative study of seven European countries. Journal of Applied Economics, 20(1), 141-168. https://doi.org/10.1016/ s1514-0326(17)30007-7

BBC Thai.(2018, June 15). Students prohibited wearing Hijab: Preserve the Buddhist place or not to respect Muslims? www. bbc.com/thai/amp/thailand-44494889

Berton, R., \& Panel, S. (2018). Alternation through death: Is gerontocracy an equilibrium? Political Research Quarterly, 71(4), 975-988. https://doi. org/10.1177/1065912918775251

Buaban,J.(2020).Islamophobiaasrepresented by Thai Buddhist organizations. Journal of Social Sciences, 50(2), 125-147.

Bunnag, J. (2007). Buddhist monk, Buddhist layman: A study of urban monastic organization in central Thailand. Cambridge University Press.

Bytheway, B. (1995). Ageism. Open University Press.

Chandaeng, P. (2019). Civil rights of Thai monks in the constitution. Journal of Religious Anthropology, 1(3), 96-105.

Doungkaew, N. (2016). Image and selfpresentation of neo-Khruba as a product of Belief. Thammasat Journal of History, 35(3), 1-19.

Eaiwsriwong, N. (2003). A sect of the king Rama V. Silapa Wathanatham. (in Thai).

Gornall, A. (2020). Rewriting Buddhism: Pali literature and monastic reform in Sri Lanka, 1157-1270. UCL Press.

Helbardt, S., Hellmann-Rajanayagam, D., \& Korff, R. (2013). Religionisation of politics in Sri Lanka, Thailand and Myanmar.
Politics, Religion E Ideology, 14(1), 36-58. https://doi.org/10.1080/21567689.2012.75 2358

Jory, P. (2002). The Vessantara Jataka, Barami, and the Bodhisatta-kings: The origin and spread of a Thai concept of power. Crossroads: An Interdisciplinary Journal of Southeast Asian Studies, 16(2), 36-78.

Julia, C. H. (2005). The compassion relief diaspora. In L. Learnman (Ed.), Buddhist missionaries in the era of globalization. University of Hawaii Press.

Kamjaiboon, A. (2019). The competency development of the royal Thai army's chaplains based on Buddhist integration. Journal of MCU Nakhondhat, 6(4), 21552173.

Kirsch, A. T. (1977). Complexity in the Thai religious system: An interpretation. The Journal of Asian Studies, 36(2), 241-266.

Kitiarsa, P. (2007). Buddha Phanit: Thailand's prosperity religion and its commodifying tactics. In Kitiarsa, P. (Ed.), Religious commodifications in Asia: Marketing gods. Routledge.

Kulabkaew, K. (2019). The politics of Thai Buddhism under the NCPO Junta (No. 8). ISEAS-Yusof Ishak Institute. https://doi. org/10.1355/9789814843744

Kulabkaew, K. (2012). In defense of Buddhism: Thai Sangha's social movement in the twenty-first century. [Ph.D. Thesis, Waseda University, Japan].

Larsson, T. (2020). Royal succession and the politics of religious purification in contemporary Thailand. Journal of Contemporary Asia, 51(1), 1-21. https:// doi.org/10.1080/00472336.2020.1849775

McCargo, D. (2004). Buddhism, democracy and identity in Thailand. Democratization, 11(4), 155-170. https:// doi.org/10.1080/1351034042000234576

Metraux, D. (1996). The Soka Gakkai: Buddhism and the creation of a harmonious and peaceful society. In 
Queen, C. S., \& King, S. B. (Eds.). Engaged Buddhism: Buddhist liberation movements in Asia. SUNY Press.

Na-Rangsi, S. (2002). Administration of the Thai Sangha: Past, present and future. The Chulalongkorn Journal of Buddhist Studies, 1(2), 59-75.

Nicholas, T. (Ed.). (1999). The Cambridge history of Southeast Asia, Vol. 2, Part. 2. The Press Syndicate of the University of Cambridge.

Puntarigvivat, T. (2003). Buddhadasa Bhikkhu and the theory of Dhammic Socialism. The Chulalongkorn Journal of Buddhist Studies, 2(2), 61-96.

Rotilă, V., \& Celmare L. (2017). Analysis of a major inequity in the budgetary wage system: Gerontocracy, arguments and solutions. In Ignatescu, A., \& Ciulei, T. (Eds.). Rethinking social action: core values in practice. LUMEN Proceedings https:// doi.org/10.18662/lumproc.rsacvp2017.66

Thirapanyo, N. \& Pipitkun, K. (2018). The Sangha Act, 2505 (Amendment No. 3, 2017) concerning political law. NEU Academic and Research Journal, 8(3), 54-60.

Office of National Buddhism. (2016). Handbook of Dhamma study grade II. Office of National Buddhism Press.

Pansa, B. (2018). Teaching and learning of Pali as traditional system of Phrapariyatidhamma in Thailand. International Journal of Multidisciplinary in Management and Tourism, 2(1), 30-37.

Rabassó, C. A., \& Rabassó, F. J. (2018). Holistic learning in "Maternalistic" management educational environment as a way to close the gender gap in Southeast Asia [Paper presentation]. Conference Proceeding on Business and Human Rights Holding Government Accountable in Asia. https:// bit.ly/2Z9IRZX.

Reynolds, C. (2015). Applied sciences for hedging risk and anticipating outcomes in police work. The Thammasat Journal of History, 1(2), 14-51.

Reynolds, C. (2016). Magic and Buddhism. In Powers, J. (Ed.), The Buddhist world. Routledge.

Sangkhawijit, N. (2017). The Sangha administration in contemporary: Problems and solutions. Journal of MCU Social science Review, 6(1). 27-40.

Sairarod, P. S., \& Kumar, M. S. (2020). The contribution of prince-priest Vajirananavarorasa to the Dhamma studies in Thailand. International Journal of Multidisciplinary Educational Research, 9(1), 121-125.

Sirimangalacariya. (1987). Maggalatthadipani Part I. Mahamakut Buddhist University.

Scott, R. (2009). Nirvana for sale?: Buddhism, wealth, and the Dhammakaya Temple in contemporary Thailand. State University of New York Press.

Tambiah, S. J. (1984). The Buddhist saints of the forest and the cult of amulets. Cambridge University Press.

Taylor, J. (1993). Forest monks and the nationstate: An anthropological and historical study in Northeastern Thailand. Institute of Southeast Asian Studies (ISEAS).

Tiyavanich, K. (1997). Forest recollections: Wandering monks in twentieth-century Thailand. University of Hawaii Press.

Tuan, N. A. (2018). A Comparison on the structure of Buddhist Sangha administrative system between Thailand and Vietnam. The Journal of International Association of Buddhist Universities (JIABU), 11(3), 65-83.

Visalo, P. (2003). Thai Buddhism in the future: Tendency and solution. Sodsri-Saritwong Foundation.

Voyce, M. (2016). Foucault, Buddhism and disciplinary rules. Taylor \& Francis.

Wilkinson, J. \& Ferraro, K. (2002). Thirty years of ageism research. In Nelson, T. 
(ed). Ageism: Stereotyping and prejudice against older persons. Massachusetts Institute of Technology.
Winichakul, T. (2015). Buddhist apologetics and a genealogy of comparative religion in Siam. Numen, 62(1), 76-99. https://doi. org/10.1163/15685276-12341356 